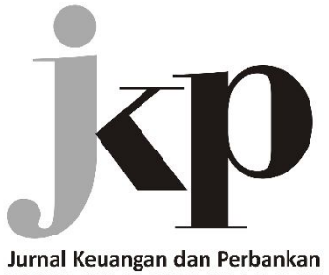

Jurnal Keuangan dan Perbankan
$U N \vee E R S 1$ Y U IVEKUEKA MALANG

Article history:

Received: 2018-05-03

Revised: 2018-06-08

Accepted: 2018-07-29
Hesti Aruninggar, Rofikoh Rokhim

Department of Management, Faculty of Economics and Business, Universitas Indonesia Jl. Prof. Dr. Sumitro Djojohadikusumo, Depok, 16424 Indonesia
Hesti Aruninggar (Indonesia), Rofikoh Rokhim (Indonesia)

\section{Bank-Specific Factors, Regional Economy, and RDBs' Non-Performing Loans throughout Indonesia}

\begin{abstract}
Regional development was directed to achieve national targets by taking into account the potential, aspirations, and development issues in the regions. One of the inclusive work programs in Indonesian Financial Services Sector Master Plan 2015-2019 was to develop regional economic potential by strengthening the function and role of the regional development bank in supporting the regional economy. We analyzed the influence of bank-specific factors and economic conditions of the regions, where headquarters of the regional development bank (RDB) operates, on non-performing loans recorded by RDBs throughout Indonesia. The research conducted at $25 \mathrm{RDBs}$ spread all over Indonesia for six years. The data used panel data regression with the Fixed Effects method due to possibility of region and time differences. We found that bank-specific factors and local economic conditions affect non-performing loans at RDBs. This can be seen from higher bank capitalization and operational inefficiency costs which had stimulated a significant rise in non-performing loans at RDBs, while increasing bank profitability had driven non-performing loans to drop significantly. Furthermore, in the factor of regional economic conditions, gross regional domestic product and inflation in the regions had a significant effect on decreasing level of non-performing loans at RDBs throughout Indonesia.
\end{abstract}

Keywords: Bank-specific Factors; Gross Regional Domestic Product; Inflation; Non-performing Loans; Regional Economic

JEL Classification: E32; G21; G28; R10; R11

Citation: Aruninggar, H., \& Rokhim, R. (2018). Bank-specific factors, regional economy, and RDBs' non-performing loans throughout Indonesia. Jurnal Keuangan dan Perbankan, 22(3), 557-567. https://doi.org/10.26905/ jkdp.v22i3.2233

\begin{abstract}
Abstrak
Pembangunan daerah diarahkan untuk mencapai target nasional dengan memperhatikan potensi, aspirasi, dan masalah pembangunan di daerah. Salah satu program kerja inklusif dalam Master Plan Sektor Jasa Keuangan Indonesia 2015-2019 adalah mengembangkan potensi ekonomi regional dengan memperkuat fungsi dan peran bank pembangunan daerah dalam mendukung perekonomian daerah. Kami menganalisis pengaruh faktor spesifik bank dan kondisi perekonomian daerah dimana kantor pusat Bank Pembangunan Daerah (BPD) beroperasi terhadap kredit bermasalah yang terjadi pada BPD di seluruh Indonesia. Penelitian dilakukan terhadap 25 BPD yang tersebar di seluruh Indonesia selama 6 tahun. Data yang digunakan merupakan regresi data panel dengan metode Fixed Effects atas kemungkinan perbedaan daerah dan waktu. Kami menemukan bahwa faktor spesifik bank dan kondisi perekonomian di daerah berpengaruh terhadap terjadinya kredit bermasalah di BPD setempat. Hal ini dapat dilihat dari semakin meningkatnya kapitalisasi bank dan biaya inefisiensi operasional akan berpengaruh signifikan terhadap meningkatnya kredit bermasalah di BPD, sedangkan semakin meningkatnya profitabilitas bank akan berpengaruh secara signifikan terhadap menurunnya kredit bermasalah di BPD. Selanjutnya dalam faktor kondisi perekonomian daerah, semakin meningkat Produk Domestik Regional Bruto dan inflasi di daerah akan berpengaruh signifikan terhadap menurunnya tingkat kredit bermasalah di BPD seluruh Indonesia.
\end{abstract}

Kata kunci: Faktor-faktor Spesifik Bank; Produk Domestik Regional Bruto; Inflasi; Kredit Bermasalah; Ekonomi Daerah
This is an open access

article under the CC-BY-SA license 
Regional development is an integral part of the national development program. Regional development is directed to achieve national targets by taking into account the potential, aspirations, and development issues in the regions. To accelerate the implementation of fair and reasonable development efforts across Indonesia, it is necessary to mobilize the capital and potential in the regions to finance regional development.

One of the inclusive work programs in the Indonesian Financial Services Sector Master Plan 20152019 is to develop regional economic potential by strengthening the function and role of the regional development bank in supporting the regional economy so that the main target to optimize the role of financial services system in the economy, maintain financial system stability, and to achieve financial self-sufficiency of the community (FSA, 2015). The work program is executed through the RDB Transformation Program launched by the President of the Republic of Indonesia in May 2015. This is in accordance with Law No. 13/1962 that stipulates that RDB has a special role in providing funding for the implementation of regional development efforts in the framework of the National Development Planning.

RDBs is a concept of Regional Bank that applied in Indonesia. Griffith-Jones, Griffith-Jones, \& Hertova (2008) state that the regional bank is a financial institution that has several important roles in regional development. Among the roles are to support the development and to raise ownership as well as efficiency as a whole. The reasons behind the importance of regional banks to function for regional economy include: (1) the focus on regional economic development, particularly in the informal sector; (2) the flexibility in following the norms, culture, and regulations in each region; (3) the better coordination with local governments; (4) the decrease in the level of imperfect information on financial markets; and (5) the consideration they are more responsive to the needs and economies of local communities.

Bulbul, Schmidt, \& Schuwer (2013) state that banks are operating at the regional level are expected to support local economies and local communities and at the same time be able to operate in accordance with general business rules. Thus the banks can be financially sustainable.

Several countries have applied the bank's regional concept. One example is the savings banks commonly called Sparkassen as commercial banks with decentralized operations and locally operated and focusing its business activities in certain regions in Germany and Erste Bank operating in Austria as a group of banks consisting of 47 regional and local banks.

RDBs in Indonesia is established as an agent of regional development to function as, among other things, a driver to promote economic growth and regional development in order to improve people's living standards, to become regional cash holders and/ or save local funds as well as one of the sources of local revenue.

Table 1. RDB Performance Indicators

\begin{tabular}{|c|c|c|c|c|c|c|c|c|c|}
\hline & 2012 & 2013 & 2014 & 2015 & 2016 & 2017 & $\begin{array}{l}\text { RDB Growth } \\
\text { (2017) }\end{array}$ & $\begin{array}{c}\text { Commercial } \\
\text { Bank Growth } \\
(2017)\end{array}$ & $\begin{array}{l}\text { Share in the } \\
\text { Industry }\end{array}$ \\
\hline $\begin{array}{l}\text { Loans } \\
\text { (IDR bn) }\end{array}$ & 218,851 & 264,541 & 301,456 & 328,759 & 357,859 & 390,372 & $9.09 \%$ & $8.24 \%$ & $8.24 \%$ \\
\hline $\begin{array}{l}\text { RDB NPL } \\
\text { (IDR bn) }\end{array}$ & 5,025 & 7,444 & 10,406 & 12,070 & 11,801 & 12,432 & $6.70 \%$ & $-0.04 \%$ & $10.24 \%$ \\
\hline
\end{tabular}

Source: FSA (2018) 
Data show that loans disbursed by RDBs until December 2017 grew by 9.09 percent with total loans of IDR 390,372 billion or 8.24 percent of the total amount disbursed by the national banking industry. Loans disbursed by RDBs were still dominated by consumer loans with a portion of 60 percent. The low proportion of productive loans provided by RDBs indicates the less optimal role showed by RDBs as a regional development agency.

The low quality of RDBs' loan disbursement is due to RDBs' weak infrastructure and resources in credit management. This can be seen from the average ratio of NPLs in RDBs that is higher than those of commercial banks. The ratio of RDBs' gross NPLs in December 2017 was 3.23 percent with those of commercial banks amounting to 2.5 percent on average. Meanwhile, RDBs' NPLs in productive loans are still considered high, reaching 8.6 percent or above the ind ustrial average of commercial banks at 2.9 percent. In addition, the portion of RDB's loan disbursement was dominated by consumer loans in contrast to the average of those recorded by commercial banks.

In providing loans, RDBs are faced with the risk of default in which the portion of non-performing loans is higher than the industrial average of commercial banks, especially in the channeling of productive loans. High default loan rates seriously affect loan collections, and this lessens banks' abil- ity to lend and thus increases the cost of borrowing (Berrios, 2013). To avoid losses due to such default, banks must be selective in processing proposed loans. Thus credit quality can be well maintained. There are several types of default in the calculation of credit risk, including delays in the repayments of principal and interest, restructuring of liabilities due to deterioration of the quality of the debtors, as well as unpaid liabilities resulting from the bankruptcy of the debtor's business.

Credit quality is determined by analyzing several factors such as the assessment of business prospects, debtor performance, and the ability to pay. The Basel Committee on Banking Supervision (2006) states that a credit is categorized as a default if the arrears of principal or interest repayments exceed 90 to 180 days or, among other, the bank assumes the debtor cannot pay full credit obligations without legal action such as foreclosure or when the debtor fails to make principal and/or interest repayments within the 90-day deadline.

Bank management must manage credit appropriately to minimize default. The purpose of credit risk management is to maximize the rate of return adjusted to bank risk and maintain credit risk exposure within acceptable parameters. This is because efficient credit risk management is a vital element for the banking system as a whole (Ho \& Yusoff, 2009).

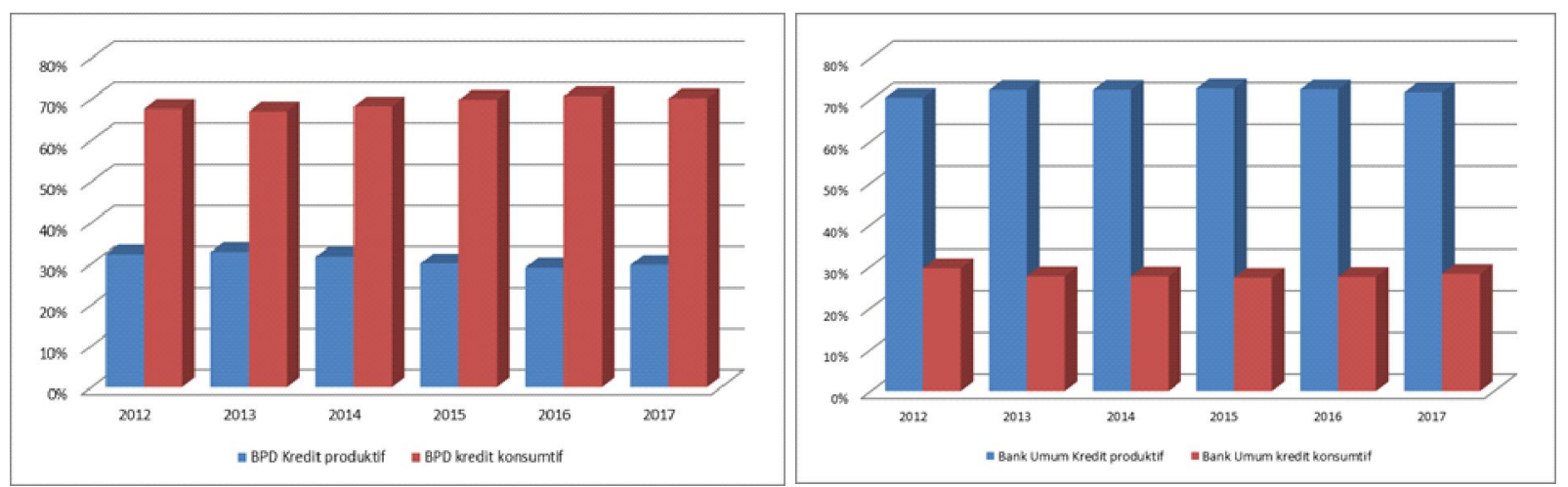

Figure 1. Charts of Loan Disbursement by RDBs and Commercial Banks Source: FSA (2018) 
According to Herrias \& Moreno (2011), banks with high NPL levels in the balance sheet also have lower lending capabilities than others. A non-performing loan is an uncollectible percentage of the loan by the terms of the credit agreement of both parties as one of the main indicators to assess the quality and level of bank solvency. The NPL is perceived as an obstacle to the economic activity of each bank. Barseghyan (2010) suggests that NPLs has widespread social and economic implications, as they reduce social output and diminishes the production growth.

A rising share of NPLs in the loan portfolio of banks signifies greater risks affecting both the liquidity and profitability of banks. Moreover, it represents a deteriorating balance sheet of banks. NPLs are especially in the spotlight for both regulators and banks as it has been linked to bank failures, and is often a harbinger to banking crises (Ghosh, 2015). Therefore, the key responsibility of the central bank and the oversight authority is to ensure stable and efficient finance that protects the interests of all participating parties. Failure in lending is always a serious concern for creditors and policymakers (Saba, Kouser, \& Azam, 2012). The surge in non-performing loans at banks may be instigated by bank-specific and macroeconomic factors.

Concerning the level of bank soundness, especially that of RDBs as a regional development agency, in performing intermediation function is seen not maximal yet, this research is focused on exploring factors that influence NPLs by taking into account both bank-specific conditions and regional economic indicators.

\section{HYPOTHESES DEVELOPMENT}

Several studies have been conducted to determine the causes of problem loans. Klein (2013) investigates NPL levels in 16 European countries and finds several specific factors affecting NPLs. Ikram et al. (2016) in their research finds the lending selection and poor procedures as the main cause of NPLs to surge in Pakistani commercial banks. Louzis, Vouldis, \& Metaxa (2012) examine the effect of macroeconomic factors on non-performing loans in the Greek banking sector by categorizing them into consumer, business, and agricultural loans and state that macroeconomic factors have an effect on NPLs.

Bucher, Dietrich, \& Hauck (2013) confirm that macroeconomic policy plays an important role in the financial stability of banks and the economy. The performance of banks in an economic downturn is thus improved only if the real economy is stabilized, to which a credible macro policy can make an important contribution. Ouhibi, Ezzeddine, \& Hammami (2017) identifies that inflation, GDP, and unemployment rates have an effect on non-performing loans in the banking sector in Tunisia and Morocco.

Furthermore, Rokhim \& Yanti (2014) in their research found that credit growth and bank management have a positive effect on the rise in RDBs' NPLs and taking into account macroeconomic factors, economic growth during the previous period will raise NPLs in the future. Ghosh (2015) identifies that two factors are causing the appearance of non-performing loans in regionally-operated banks, namely the internal factor, in this case, bank specification, and the external factor, namely the economic conditions in the area where the bank operates.

The effect of bank capitalization on NPLs can be slightly ambiguous. On the one hand, the management of undercapitalized banks has a moral hazard incentive to engage in risky lending practices along with the poor assessment of loans and debtors (Keeton \& Morris, 1987). The 'moral hazard' hypothesis implies an inverse relationship between equity capital and NPLs. On the other hand, the management of highly capitalized banks is likely to have a credit policy with the notion of "too big to fail" (Rajan, 1994), which implies a positive relation- 
ship between capital and NPLs. Bank capitalization can be measured by total equity capital divided by total assets, according to Louzis, Vouldis, \& Metaxa (2012), Macit (2012), and Klein (2013).

$\mathrm{H}_{1}$ : bank capitalization has positive effects on RDBs' non-performing loans

Keeton (1999) argues that banks will raise loans in two ways, reducing interest on new loans and downgrading credit standards for loans to be provided. For example, by reducing the amount of collateral, approving loans for borrowers with poor records, or the bank has little evidence that borrowers have sufficient cash flow to pay off their debts. Assuming that banks downgrade credit standards and reduce interest rates to increase the total loans provided, this will cause greater potential future losses. Gaiotti (2013) also argues that credit market distress has its most extreme effects in a business cycle downturn. The dynamics of the credit cycle is related to the business cycle; the deeper in recession the economy, the stronger disincentive lending accelerator effect in banks. This can be explained by the circumstance that an important source for bank liquidity is the timely collection of loans and their corresponding interest income. The researchers measure the loan-to-asset ratio as used by Klein (2013) and Ghosh (2015). In addition to measuring the level of liquidity, this measurement can also identify the ups and downs of the proportion of loans granted.

$\mathrm{H}_{2}$ : loan-to-assets ratio has positive effects on RDBs' non-performing loans

Operational efficiency is a way of utilizing inputs to produce outputs used to measure the performance of an active unit. The effect of efficiency on non-performing loans remains ambiguous. On the one hand, according to the skimping hypothesis put forward by Berger \& DeYoung (1997), banks that use fewer resources to monitor loan risk will be more cost-effective but will see their problem loans surge in the future. On the other hand, as stated by Ho \& Yussoff (2009), high cost-related inefficiency will raise non-performing loans, which is in line with the "bad management" hypothesis. This is due to a poor ability in assessing and monitoring loans. Thus, that serious inefficiency will have an impact on the increase of non-performing loans. This is in line with research conducted by Louzis, Vouldis, \& Metaxa (2012) and Ghosh (2015). The researchers measured the operational efficiency with operating expenses divided by operating income referring to Louzis, Vouldis, \& Metaxa (2012) and Maryandi, Yaya, \& Supriyono (2016).

$\mathrm{H}_{3}$ : the cost of operational inefficiency has positive effects on RDBs' non-performing loans

Highly profitable banks have less incentive to engage in high-risk activities. Thus, profitability is expected to have a negative impact on the NPL, which is in accordance with the 'bad management' hypothesis of Berger \& DeYoung (1997). As a rebuttal, higher profits can also raise NPLs. This possibility is shown in the Rajan model (1994), where credit policy is not determined solely by the maximization of bank earnings but also by the short-term reputation of bank management. As a result, bank management tries to manipulate current income by using the 'liberal credit policy'. In this way, the bank can try to convince the market for its analytical capabilities by raising its current income at the expense of NPLs supposed to surge in the future. The researchers measure profit by using the return-to asset (ROA) ratio of the banks in each region.

$\mathrm{H}_{4}$ : bank profitability has negative effects on RDBs' non-performing loans

The level of economic activity is the most important determinant both in supply and demand for credit (Ceh, Dumicic, \& Krznar, 2011). If the economy in a country declines, it will have an im- 
pact on the deteriorating quality of banks. The debtors' defaults in times of economic distress can, therefore, propagate into default by solvent borrowers that cannot obtain credits and expand their business (Trautmann \& Vlahu, 2013). Beck, Jakubik, \& Piloui (2013) also found GDP growth as one of the key drivers explaining variations in non-performing loans. Meanwhile, Rokhim \& Yanti (2014) stated that when economic growth improves, banks tend to provide more loans, resulting in a potential increase in NPLs. But over time, the provision of loans that are not based on strict standards will raise NPLs in the future. The researchers used the GRDP rate in each province, where RDB headquarters is located. This regional economic variable highlights the effect of the business cycle in each region on the quality of loans provided by RDBs. This variable is based on research conducted by Rokhim \& Yanti (2014) and Ghosh (2015).

$\mathrm{H}_{5}$ : GRDP has negative effects on RDBs' non-performing loans

Nkusu (2011) and Skarica (2014) stated that high inflation would disrupt debt repayment and thus increase non-performing loans. The impact of inflation will result in the weakening ability of customers to repay their debts due to the decline in people's actual income, also triggering uncertainty for business persons and decision makers, with ac- tual interest rates becoming uncompetitive. However, according to Ghosh (2015), inflation can have a negative impact because it can reduce the actual value, resulting in the ease of repayments. The researchers measure inflation based on the consumer price index on the provincial capital where the headquarters of RDB is located. This variable is taken in accordance with Ghosh's research (2015).

$\mathrm{H}_{6}$ : regional inflation rate has negative effects on RDBs' non-performing loans

Hang (2015) highlighted labor market fluctuations as an important economic driver of credit risk variations. Ghosh (2015) in his research stated that the increase in unemployment rates in the region would raise non-performing loans due to debtors' failure to repay their debts. The researchers measure the unemployment rate in the provinces, where RDBs' head offices are located. This variable is taken in accordance with Ghosh's research (2015).

$\mathrm{H}_{7}$ : the regional unemployment rate has positive effects on RDBs' non-performing loans

\section{METHODS}

This study aims to find out whether bank-specific factors and local economic conditions affect the level of non-performing loans in the regional development banks. The bank's NPL level represents

Table 2. Details of the Independent Variables of Research

\begin{tabular}{lll}
\hline \multicolumn{1}{c}{ Variable } & \multicolumn{1}{c}{ Description } & Source \\
\hline $\begin{array}{l}\text { Banking industry-specific variables } \\
\text { Capitalization }\end{array}$ & Equity capital-to-assets & FSA \\
$\begin{array}{l}\text { Liquidity } \\
\text { Operational efficiency } \\
\text { Return on assets }\end{array}$ & Loans-to-assets & FSA \\
& Operating expenses to operating income & FSA \\
\hline Regional economic conditions & Net pre-tax income-to-total assets & FSA \\
$\begin{array}{l}\text { GRDP } \\
\text { Regional inflation }\end{array} \quad$ Actual GRDP & Statistics Indonesia \\
$\quad$ Unemployment rate & Consumer Price Index & Statistics Indonesia \\
& Unemployed-to-labor force & Statistics Indonesia \\
\hline
\end{tabular}


the dependent variable in this study. The independent variable consists of bank-specific factors such as bank capitalization, bank liquidity, bank operational efficiency, and bank profitability, while the regional economic factors are represented by variables like GRDP, regional inflation rate, and regional unemployment rate.

This study uses the dependent variable in the form of NPL as a proxy of the level of non-performing loans and the independent variables that are divided into two groups, namely the bank-specific factors and the economic conditions of the area where the bank headquarters operates.

The overall research variables can be modeled as follows:

$$
\begin{aligned}
N P L_{i, t}= & \beta_{0}+\beta_{1} B C_{i, t}+\beta_{2} L A R_{i, t}+\beta_{3} O E_{i, t}+ \\
& \beta_{4} R O A_{i, t}+\beta_{5} G R D P_{i, t}+\beta_{6} \text { INFReg }_{i, t}+ \\
& \beta_{7} U E R e g_{i, t}+\varepsilon_{i, t}
\end{aligned}
$$

Where:

$N P L_{i, t} \quad$ : non-performing loans of bank $i$ in quarter $\mathrm{t}$ as a dependent variable

$B C_{i, t} \quad$ : capitalization of bank $i$ in quarter $t$.

$L A R_{i, t} \quad$ : loan-to-asset ratio of bank $i$ in quarter $t$.

$O E_{i, t} \quad$ : operational efficiency level of bank $i$ in quarter $t$.

$G R D P_{i} \quad$ : GRDP of region $i$ in quarter $t$.

INFReg $_{i, t}$ : inflation rate in region $i$ in quarter $t$.

$U E R e g_{i, t}$ : unemployment rate in region $i$ in quarter $t$.

$\beta_{1}-\beta_{7}$ : regression coefficients of each independent variable.

$\varepsilon \quad$ : error term

\section{RESULTS}

\section{Descriptive Statistics}

Table 3 shows the descriptive statistics of this study. The number of banks surveyed in this study is 25 RDBs, except two for failing to meet the criteria. The two are BPD Aceh that transformed into a sharia bank in May 2015 and BPD Banten that started operations in July 2016. The research was conducted on a quarterly basis for six years from 2012 to 2017 with 600 observations.

The value of the dependent variable, which is the highest NPL, was recorded by BPD Papua in the first quarter of 2017, amounting to 19.05 percent, caused by the decline in debtor business and the fraud committed by the board of the RDB.

The bank-specific factors are as follows: (1) the highest capitalization of 22.34 percent was recorded by BPD Central Kalimantan in the fourth quarter of 2017 due to an increase in core capital following the fulfillment of paid-up capital by shareholders (BPD Kalteng, 2018); (2) the highest loanto-asset ratio was 80.26 percent, recorded by BPD North Sulawesi and Gorontalo in the fourth quarter of 2015 due to the increased lending by the bank (BPD Sulutgo, 2016); (3) the highest inefficiency belonged to BPD Papua, which was recorded in the second quarter of 2017, due to its efforts to settle non-performing loans; and (4) the lowest profitability was booked by BPD Kaltimtara in the second quarter of 2014 due to a decline of 23.58 percent in the bank's gross profit (BPD Kaltimtara, 2015).

The factors of regional economic conditions are as follows: (1) the lowest GRDP of -15.54 percent was seen in West Nusa Tenggara in the second quarter of 2017 due to the declining performance of the mining sector and the reduced excavation activities in the metal ore sub-sector up to 26.98 percent (Statistics Indonesia, 2017); (2) the highest quarterly inflation rate was 7.9 percent recorded in Ambon in the third quarter of 2013 due to the increased demand in the food and beverage sector (Statistics Indonesia, 2013); and (3) the highest unemployment rate of 10.59 percent was recorded in Jakarta in 2012, but the unemployment rate in the Special Capital Region fluctuated with the downward trend especially during the last 5 years, at 1.05 percent per year due to the increasing number of online-based public transportation riders/drivers (Statistics Indonesia, 2018). 


\section{Regression Analysis}

The first step to determine the type of model to be used in the panel data regression is the Chow and Haussmann tests. The Chow test is performed to see which model is best used between the pooled least square model and the fixed effects model. The Haussmann test is conducted to compare the fixed effects model with the random effects model.

Based on Table 4 it can be seen that the probability of chi-square of the Chow test result is smaller than $\alpha=5$ percent, that is 0,0000 . Thus H-0 is rejected, and the selected model is the fixed effects model. Furthermore, the probability of cross-sec- tion random from the Haussmann test shows that the result is smaller than $\alpha=5$ percent, that is 0.015 . Thus $\mathrm{H}_{0}$ is rejected, and the selected model is the fixed effects model.

The fixed effects model regression is done with the generalized least square method (cross section weights), and the result shows that the coefficient of bank-specific factors such as capitalization, operational efficiency, and profitability support the research hypothesis. Furthermore, the coefficients on regional economic factors such as GRDP, regional inflation rate, and regional unemployment rate also support the initial hypothesis.

Table 3. Statistical Description

\begin{tabular}{lcccccccc}
\hline & NPL & BC & LAR & OE & ROA & GRDP & INFR & UER \\
\hline Mean & 0.027326 & 0.115479 & 0.582127 & 0.718044 & 0.031125 & 0.057713 & 0.012838 & 0.049070 \\
Median & 0.018850 & 0.112393 & 0.586480 & 0.722900 & 0.030600 & 0.055550 & 0.011150 & 0.045069 \\
Maximum & 0.190500 & 0.223442 & 0.802662 & 1.341000 & 0.069400 & 0.340800 & 0.079000 & 0.105955 \\
Minimum & 0.000100 & 0.051054 & 0.270492 & 0.006086 & -0.033200 & -0.155500 & -0.040400 & 0.012802 \\
Std. Dev. & 0.026555 & 0.028602 & 0.086766 & 0.131814 & 0.011631 & 0.034702 & 0.013795 & 0.019002 \\
\hline
\end{tabular}

Table 4. The Chow dan Haussmann Test Results

\begin{tabular}{llc}
\hline \multicolumn{1}{c}{ Types of Test } & \multicolumn{1}{c}{ Effects Test } & Probability \\
\hline Chow Test & Cross-section F & 0.0000 \\
Haussmann Test & Cross-section random & 0.0084 \\
\hline
\end{tabular}

Table 5. The result of the Fixed Effects Model Estimation

\begin{tabular}{|c|c|c|c|c|}
\hline Variable & Coefficient & t-Statistic & Prob. & Significance \\
\hline $\mathrm{C}$ & 0.008165 & & & \\
\hline Bank capitalization & 0.091470 & 1.929157 & 0.0000 & Significant \\
\hline Liquidity & -0.000135 & 5.785798 & 0.9718 & Not significant \\
\hline Operational efficiency & 0.020701 & -0.035428 & 0.0000 & Significant \\
\hline Bank profitability & -0.105848 & 6.601611 & 0.0032 & Significant \\
\hline GRDP & -0.045305 & -2.962494 & 0.0035 & Significant \\
\hline Regional inflation & -0.041823 & -2.762689 & 0.0252 & Significant \\
\hline Unemployment rate & 0.007626 & -2.244963 & 0.8179 & Not significant \\
\hline R-squared & 0.819483 & & & \\
\hline Adjusted R-squared & 0.809543 & & & \\
\hline Sum of squared residuals & 0.088861 & & & \\
\hline F-statistic & 82.44576 & & & \\
\hline Prob (F-statistic) & 0.000000 & & & \\
\hline
\end{tabular}

Source: Researchers, 2018 
The estimation results show the value of RSquare coefficient of 0.819483 , implying that the NPL variable can be explained by the bank-specific variables such as liquidity, capitalization, operational efficiency, and profitability, as well as regional economic indicators such as GRDP, inflation, and unemployment rate of 81.94 percent, while the remaining 19.06 percent is the contribution of other variables that are not included in the study.

\section{DISCUSSION}

Based on the regression results, it can be observed that the bank-specific factors simultaneously affect non-performing loans in RDBs. This is shown by the probability value in the variables of bank capitalization, operational inefficiency, and profitability that are higher than the chi-square value, resulting in the rejection of $\mathrm{H}_{0}$. Meanwhile, the results of this study show that the value of the loanto-asset ratio does not significantly affect $\mathrm{RDBs}^{\prime}$ nonperforming loans. The insignificant value in the loanto-asset ratio is made possible because the biggest portion of loans disbursed by RDBS goes to the consumer sector with relatively less risk compared to the disbursement to the productive sector.

Bank capitalization, operational efficiency, and profitability influence with different coefficients. The bank capitalization shows significant positive coefficient results in accordance with research conducted by Louzis, Vouldis, \& Metaxa (2012), Macit (2012), Klein (2013), and Ghosh (2015). Banks with large capital can implement the liberal credit policy referring to the notion of 'too big to fail' (Rajan, 1994). Furthermore, bank's level of efficiency shows the result of significant positive coefficients that are in line with research conducted by Ghosh (2015), where high-cost inefficiency will raise NPLs in accordance with the theory of "bad management". While the profitability level of the bank shows significant negative coefficients that support the theory put forward by Berger \& DeYoung (1997) and Ghosh (2015) that profitable banks have fewer incentives to engage in high-risk activities, thus the probability is expected to have a negative impact on NPLs.

Regression analysis results for the regional economic conditions indicate that the variables of GRDP and regional inflation have an effect on RDBs' non-performing loans. The result is proved by the probability value of each variable of 0.0035 and 0.0252 . GRDP and regional inflation have negative coefficients in influencing RDBs' NPLs. These results support the theory put forward by Ghosh (2015), which states that higher GRDP and regional inflation will reduce NPLs.

Meanwhile, the regional unemployment rate shows positive coefficients but without a significant effect on RDBs' NPLs. This is possible because most of the RDBs' loans were disbursed not to the main employment-generating sectors in the region. FSA data (2018) show that the highest level of RDBs' nonperforming loans during the period 2012-2017 was seen in the mining and quarrying sector with an average of 21.10 percent and the transportation, warehousing, and communication sector with an average of 16.55 percent. Both sectors only accounted for 0.5 percent and 1.5 percent of the total loans respectively. These figures are far lower if compared to the household sector and the trade sectors which account for 55 percent and 13 percent respectively of the average total loans provided during the same period with a lower average of NPLs. Based on data from Statistics Indonesia (2018), the mining sector and the transportation, warehousing, and communication sector recorded only 1.5 percent and 4.5 percent respectively in terms of employment absorption. Thus, the surging unemployment did not have a major impact on RDBs.

\section{CONCLUSION AND SUGGESTIONS}

\section{Conclusion}

The assessment of the overall asset quality in the banking industry is an important element for 
the macroprudential policy. Comprehensive understanding is needed in facilitating and identifying the key vulnerabilities of the banking sector especially regarding loans provided. Large capitalization may be useful to ensure more profit, but it can also raise NPLs. This is in line with the hypothesis of "too big to fail". In addition, the results of this study also provide evidence that banks operating in the region are also vulnerable to the economic conditions of the region. The evidence can also be seen when the economy declines, the level of NPLs will rise.

\section{Suggestions}

Future research is expected to increase the number of time periods and measurement variables to obtain results that can help identify factors that describe the influence of bank-specific factors and regional economic conditions. Given the limitations of data and variables used, it is also expected that the next researcher can see the influence of each variable on the RDBs' types of loans, namely consumer loans, investment loans, and working capital loans.

\section{References}

Bank DKI. (2014). Annual Report 2013, www.bankdki.co.id. Accessed on 14 April 2018.

Bank Kalteng. (2018). Annual Report 2017, www.bankkalteng.co.id. Accessed on 14 April 2018.

Bank Kaltimtara. (2016). Annual Report 2015, www.bankaltimtara.co.id. Accessed on 14 April 2018.

Bank NTB. (2017). Annual Report 2013, www. bankntb.co.id. Accessed on 14 April 2018.

Bank Papua. (2017). Annual Report 2016, www.bankpapua.co.id. Accessed on 14 April 2018.

Bank Sulutgo. (2017). Annual Report 2016, www.banksulutgo.co.id. Accessed on 14 April 2018.

Barseghyan, L. (2010). Non-performing loans, prospective bailouts, and Japan's slowdown. Journal of Monetary Economics, 57(7), 873-890. https://doi.org/ 10.1016/j.jmoneco. 2010.08.002

Bank for International Settlements. (2006). Basel II: International Convergence of Capital Measurement and Capital Standards: A Revised Framework - Comprehen- sive Version. Basel Committee on Banking Supervision. Retrieved from: https://www. bis.org/publ/bcbs128.htm

Beck, R., Jakubik, P., \& Piloui, A. (2013). Non-performing loans what matters in addition to the economic cycle? European Central Bank Working Paper. Retrieved from: https://papers.ssrn.com/ sol3/papers.cfm?abstract_id= 2214971

Berger, A. N., \& DeYoung, R. (1997). Problem loans and cost efficiency in commercial banks. Journal of Banking and Finance, 21(6), 849-870. https:// doi.org/10.1016/S03784266(97)00003-4.

Berrios, M. R. (2013). The relationship between bank credit risk and profitability and liquidity. The International Journal of Business and Finance Research, 7(3), 105118. Retrieved from: https:// papers.ssrn.com / sol3 / papers.cfm?abstract_id=2149816

Bulbul, D., Schmidt, R. H., \& Schuwer, U. (2013). Savings bank and cooperative banks in Europe. Goethe University Frankfurt White Paper Series No. 5.
Bucher, M., Dietrich, D., \& Hauck, A. (2013). Business cycles, bank credit, and crises. Economics Letters, 120, 229-231. https:// doi.org/10.1016/j.econlet. 2013.04.029.

Ceh, A. M., Dumicic, M., \& Krznar, I. (2011). A credit market disequilibrium modal and periods of credit crunch. Croatian National Bank Working Paper 28.

Gaiotti, E. (2013). Credit availability and investment: Lessons from the "great recession". European Economic Review, 59, 212-227. https://doi.org/10.1016/ j.euroecorev.2012.12.007.

Ghosh, A. (2015). Banking-industry specific and regional economic determinants of non-performing loans: Evidence from US States. Journal of Financial Stability, 93-104. http:/ /dx.doi.org /10.1016/j.jfs.2015.08.004

Griffith-Jones, S., Griffith-Jones, D., \& Hertova, D. (2008). Enhancing the role of regional development bank. United Nations $P a-$ per G-24.

Hang, B. (2015). Unemployment and credit risk. Job Market Working Paper 15/08. 


\section{Bank-Specific Factors, Regional Economy, and RDBs' Non-Performing Loans throughout Indonesia}

Hesti Aruninggar \& Rofikoh Rokhim

Herrias, R., \& Moreno, J. O. (2011). Spillovers and long run diffusion of non-performing loans risk. ITAM School of Business.

Ho, C. S. F., \& Yusoff, N. I. (2009). A preliminary study on credit risk management strategies of selected financial institutions in Malaysia. Jurnal Pengurusan, 28, 45-65. http://ejournals. ukm.my/pengurusan/article/ view/893

Ikram, A., Su, Q., Ijaz, F., \& Fiaz, M. (2016). Determinants of nonperforming loans: An empirical investigation of bank-specific microeconomics factors. The Journal of Applied Business Research, 3(10): 1723-1736. https:/ /doi.org/10.19030/jabr.v32i6. 9819

Keeton, W., \& Morris, C. (1987). Why do banks' loan losses differ? Economic Review, 72(5), 3-21.

Klein, N. (2013). Non-performing loans in CESEE: Determinants and impact on macroeconomic performance. International Monetary Fund Working Paper 13/72.

Laws of the Republic of Indonesia No. 13/1962 dated 16 August 1962 on the Basic Provisions of Regional Development Banks. Accessed on 10 February 2018. Retrieved from: https:// bhpn.go.id.

Louzis, D. P., Vouldis, A. T., \& Metaxas, V. L. (2012). Macroeconomic and bank-specific determinants on non-performing loans in Greece: A com- parative study of mortgage, business, and consumer loan portfolios. J. Bank. Financ. 36, 1012-1027. https:// doi.org/ 10.1016/j.jbankfin.2011.10.012.

Macit, F. (2012). Bank speciûc and macroeconomic determinants of proûtability: Evidence from participation banks in Turkey. Economics Bulletin, 32(1), 586595. Retrieved from: https:// ideas.repec.org/a/ebl/ecbull/ eb-11-00769.html

Maryandi, M. S., Yaya, R., \& Supriyono, E. (2016). Analisis pengaruh faktor internal bank terhadap non performing loan berdasarkan generalized method of moment. Jurnal Keuangan dan Perbankan, 20(3), 496-506. http://jurnal.unmer. ac.id/index.php/jkdp/article/view/263

Nkusu, M. (2011). Non-performing Loans and macro-financial vulnerabilities in advanced economies. IMF Working Paper WP/11/161.

Ouhibi, S., Ezzeddine, S., \& Hammami, A. (2017). Non-performing loans and systemic risk: Empirical evidence to Tunisia and Morocco. Arabian J Bus Manag Review, 7, 296. http:// dx.doi.org/10.20431/23490349.0502001 .

Rajan, R. (1994). Why bank policies fluctuate: A theory and some evidence. Q. J. Econ., 109, 399441. https://doi.org/10.2307/ 2118468.
Rokhim, R., \& Yanti, M. I. S. M. (2014). Risiko NPL kredit Bank Pembangunan Daerah sebagai regional champion. Jurnal Keuangan dan Perbankan, 18(1), 120-129. Retrieved from: http:/ /jurnal.unmer.ac.id/index. php/jkdp/article/view/783

Saba, I., Kouser, R., \& Azeem, M. (2012). Determinants of nonperforming loans: Case of US banking sector. The Romanian Economic Journal, 44, 125-136. Retrieved from: https:// ideas.repec.org/a/rej/journl/ v15y2012i44p125-136.html

Skarica, B. (2014). Determinants of non-performing loans in Central and Eastern European countries. Financial Theory and Practice, Institute of Public Finance, 38(1), 37-59. Retrieved from: https://ideas.repec.org/ a/ipf/finteo/v38y2014i1p3759.html

Sparkassentiftung. Accessed on 21 April 2018. |https://sparkassenstiftung.de.

Statistics Indonesia. (2012-2017). Statistics Official News. Accessed on 23 January 2017. https:// bps.go.id.

Trautmann, S. T., \& Vlahu, R. (2013). Strategic loan defaults and coordination: An experimental analysis. Journal of Banking $\mathcal{E}$ Finance, 37, 747-760. https:// doi.org/10.1016/j.jbankfin. 2012.10.019. 